J. Dairy Sci. 92:638-644

doi:10.3168/jds.2008-1120

(c) American Dairy Science Association, 2009.

\title{
The quality of commercial wheat silages in Israel ${ }^{1}$
}

\author{
Z. G. Weinberg, ${ }^{* 2}$ Y. Chen, ${ }^{*}$ and R. Solomon† \\ *Forage Preservation and By-Products Research Unit, Department of Food Science, Agricultural Research Organization, The Volcani Center, \\ PO Box 6, Bet Dagan 50250, Israel \\ †Department of Dairy Cattle, Extension Service, Israeli Ministry of Agriculture and Rural Development, Bet Dagan 50250, Israel
}

\begin{abstract}
Wheat silages are the major roughage for high-producing lactating dairy cows in Israel; therefore, their quality is important. The main objective of the current study was to determine the preservation status and nutritional quality of commercial wheat silages in Israel. An additional objective was to develop predictive equations for dry matter digestibility (DMD) and neutral detergent fiber digestibility (NDFD) based on chemical composition of the silages, which would permit estimation of the digestibility from chemical composition. A total of 143 commercial wheat silages were sampled and analyzed for 3 yr. Fourteen random samples that were not included in the regression analysis were used to validate the equations by the bias and error of the model. Results revealed that wheat silages were quite sensitive to aerobic exposure; additives resulted in some improvement of the aerobic stability. After choosing the significant terms from ash, crude protein $(\mathrm{CP})$, $\mathrm{NDF}$, acid detergent fiber (ADF), and acid detergent lignin (ADL) by PROC STEPWISE of SAS, the following prediction equations were obtained from all 143 samples: $\mathrm{DMD}=86.3+(0.70 \times \mathrm{CP})-(0.46 \times \mathrm{ADF})$ $-(1.67 \times \mathrm{ADL}) ;$ and $\mathrm{NDFD}=20.3+(1.00 \times \mathrm{CP})+$ $(1.16 \times \mathrm{NDF})-(0.88 \times \mathrm{ADF})-(2.25 \times \mathrm{ADL})$. The bias and the error of the prediction model for DMD were approximately 0.006 and 0.065 , respectively; the bias and error for NDFD were approximately 0.007 and 0.118 , respectively. It was concluded that the prediction model for DMD was quite adequate, whereas that for NDFD was less acceptable.
\end{abstract}

Key words: commercial wheat silage, digestibility, regression analysis

\section{INTRODUCTION}

In Israel, wheat silages are the major roughage for high-producing dairy cows; therefore, their quality is

\footnotetext{
Received February 24, 2008.

Accepted October 12, 2008.

${ }^{1}$ Contribution from the Agricultural Research Organization, The Volcani Center, Bet Dagan, Israel. No. 508/08-E, 2008 Series.

${ }^{2}$ Corresponding author: zgw@volcani.agri.gov.il
}

important. In the semiarid climate in Israel, wheat for silage is grown under winter rain and harvested in the spring, usually at the milk stage of maturity. However, some farmers prefer to harvest at the flowering stage of maturity, and in some cases, wheat for silage is harvested at the dough stage. The wheat cultivars that are selected for silage are the most promising in terms of yield, ensilability, and nutritive value; these include early- and late-maturing varieties (Ashbell et al., 1997).

Rapid changes take place in the composition of wheat plants during the 3 to $4 \mathrm{wk}$ of development from the flowering to the dough stage of maturity. At the flowering stage, the plants are too moist for ensiling and should be wilted first; they are high in CP, water-soluble carbohydrates (WSC), and fiber (i.e., NDF). As the plants mature, the DM content increases, whereas the concentrations of CP, WSC, and NDF decrease (Weinberg et al., 1991). The stage of maturity at harvest affects the yield, silage quality, and nutritive value of wheat silages. Arieli and Adin (1994) found that silage prepared from wheat that had been harvested at the flowering stage was superior to that from wheat that had been harvested at the end of the milk stage in terms of NDF digestibility (NDFD) and milk yields of lactating cows. In contrast, Ashbell et al. (1997) concluded that harvesting wheat at the milk stage of maturity was optimal for yields of DM and degradable NDF. In practice, however, the conditions on the farms dictate the timing of harvest.

Most of the research pertaining to wheat silages in Israel has been performed under laboratory conditions in mini silos, but limited research has been conducted on farm-produced silages. This research addressed the effects of cultivar, stage of maturity at harvest, and various additives on the quality of wheat silage. Commercial silages in Israel are stored in bunker silos of various sizes; these contain from several hundreds to several thousands of tons of DM.

The objective of the present study was to determine the quality status of commercial wheat silages in Israel. This included both the preservation and nutritive aspects. In addition, an attempt was made to develop predictive equations for DM and NDFD based on the 
major chemical constituents of the silage (ash, CP, NDF, ADF, and acid detergent lignin (ADL), to be able to assess wheat silage digestibility by chemical composition.

\section{MATERIALS AND METHODS}

\section{Experimental Procedures}

A total of 143 commercial bunker wheat silages were sampled during a 3 -yr period, 50 in 2004, 50 in 2005, and 43 in 2006. The silages were sampled from most geographical regions in Israel, ranging from relatively rainy and cool areas in the north to arid and warm areas in the south. At sampling, data were collected from participating producers; these data included wheat cultivar, stage of maturity at harvest (either flowering, milk, or dough), and the use of silage additives (chemical, inoculant, or none). The silage samples were collected 2 to 4 mo after ensiling.

Ten to 15 subsamples per silo were taken from random locations across the exposed silage face at a depth of 5 to $10 \mathrm{~cm}$. Approximately $2 \mathrm{~kg}$ of silage from blended subsamples from each bunker silo were pooled and brought to the laboratory in insulated coolers. The samples were mixed thoroughly, and approximately 1 $\mathrm{kg}$ was allocated for a 5 -d aerobic stability test conducted in recycled 1.5-L polyethylene-terephthalate (soft drink) bottles. This analysis system consisted of 2 parts cut from each plastic bottle. Approximately 250 to $300 \mathrm{~g}$ of silage was packed into the neck portion of the plastic bottle (in triplicate); holes were drilled through the plastic to allow penetration by air. This part of the bottle was then turned upside down and placed on top of beakers cut from the lower parts of the bottle. The lower part of each bottle contained 100 $\mathrm{mL}$ of $20 \% \mathrm{KOH}$ to absorb the $\mathrm{CO}_{2}$ that was produced during aerobic exposure. The $\mathrm{CO}_{2}$ was determined by titration with $1 \mathrm{~N} \mathrm{HCl}$. In these systems, change in $\mathrm{pH}$, production of $\mathrm{CO}_{2}$, numbers of yeasts and molds, and visual appearance served as spoilage indicators (Ashbell et al., 1991). Approximately 250-g quantities of the silage samples were used for chemical and microbiological analyses. The remainder (approximately $750 \mathrm{~g}$ ) was dried at $60^{\circ} \mathrm{C}$ for $48 \mathrm{~h}$ and ground to pass through a 1-mm screen before assessment of nutritive value in the laboratory.

\section{Analyses}

Dry matter was determined in triplicate by oven drying for $48 \mathrm{~h}$ at $60^{\circ} \mathrm{C}$. Ash content was obtained in a muffle oven after $3 \mathrm{~h}$ at $550^{\circ} \mathrm{C}$. Crude protein was determined by the Kjeldahl method. Concentrations of WSC were determined by the phenol-sulfuric acid method according to Dubois et al. (1956). Lactic acid was determined by the spectrophotometric method of Barker and Summerson (1941). Ethanol and VFA were determined in aqueous extracts with a gas chromatograph equipped with a semicapillary nitroterephthalic acid-modified polyethylene glycol column (FFAP, Hewlett-Packard, Waldborn, Germany), over a temperature range of 40 to $230^{\circ} \mathrm{C}$. Fiber fractions were determined according to Van Soest et al. (1991) with an Ankom fiber analyzer (Ankom Technology, Macedon, NY). The following fractions were determined: NDF was assayed with a heat-stable amylase and expressed inclusive of residual ash (aNDF - NDF); ADF was expressed inclusive of residual ash (ADF - ADF); ADL was determined by solubilization of cellulose with sulfuric acid [lignin(sa) - lignin, ADL). Dry matter digestibility (DMD) and NDFD were determined according to the 2-stage fermentation technique of Tilley and Terry (1963), with all samples in triplicate. Rumen fluid was obtained from a ruminally fistulated Holstein dry cow fed $6 \mathrm{~kg}$ of DM of wheat hay and $4 \mathrm{~kg}$ of DM of TMR containing 30\% concentrated grains, $35 \%$ wheat and corn silages, $15 \%$ soybean and sunflower meals, and $20 \%$ by-products (cottonseed, wheat bran, and gluten feed). Microbiological evaluation included enumeration of yeasts and molds on spread-plate malt extract agar (Difco, Detroit, MI) acidified to $\mathrm{pH} 4.0$ with lactic acid. The plates were incubated for $3 \mathrm{~d}$ at $30^{\circ} \mathrm{C}$. The microbiological analysis was performed on a single representative silage sample from each silo.

\section{Statistical Analysis}

Statistical analysis of the fermentation and aerobic stability parameters and of the chemical composition included ANOVA and Tukey's Studentized range test, which were performed by PROC GLM (SAS Institute, 1982). The effects tested were maturity (flowering, milk, dough) and geographical area (north, central, south). The additive effect (with vs. without any additive) on aerobic stability was evaluated by $t$-test. Concentrations of DMD and NDFD were regressed on CP, NDF, ADF, ADL, and ash by using PROC STEPWISE (SAS Institute, 1982). Validation of the most appropriate prediction equations for DMD and NDFD obtained from the stepwise regression analysis were performed as follows: 14 random samples $(10 \%)$ were omitted from the database, and prediction equations for DMD and NDFD were obtained by using PROC GLM of SAS. The chemical composition of the 14 excluded samples was used to obtain the bias and the error of the model. These were computed from the differences between the observed (actually measured) and predicted values for 
Table 1. Preservation parameters of the wheat silages

\begin{tabular}{|c|c|c|c|}
\hline Parameter & Minimum & Maximum & Average \\
\hline \multicolumn{4}{|l|}{ Fresh silage sample } \\
\hline $\mathrm{DM}, \mathrm{g} / \mathrm{kg} \pm \mathrm{SD}$ & 244 & 460 & $345 \pm 42$ \\
\hline $\mathrm{pH}$ & 3.4 & 4.9 & $3.8 \pm 0.2$ \\
\hline Lactic acid, $\mathrm{g} / \mathrm{kg}$ of $\mathrm{DM} \pm \mathrm{SD}$ & 0 & 113 & $56 \pm 18$ \\
\hline Ethanol, g/kg of DM \pm SD & 0 & 30 & $4 \pm 5$ \\
\hline Acetic acid, $\mathrm{g} / \mathrm{kg}$ of $\mathrm{DM} \pm \mathrm{SD}$ & 4 & 69 & $26 \pm 9$ \\
\hline Propionic acid, g/kg of DM & 0 & 8 & $<1$ \\
\hline Butyric acid, $\mathrm{g} / \mathrm{kg}$ of $\mathrm{DM}$ & 0 & 8 & $<1$ \\
\hline Yeasts $^{1}$ & $<2.0$ & 9.0 & $4.2 \pm 2.0$ \\
\hline Molds $^{1}$ & $<2.0$ & 9.0 & $3.0 \pm 2.3$ \\
\hline \multicolumn{4}{|l|}{ After aerobic exposure } \\
\hline $\mathrm{pH}$ & 3.5 & 8.3 & $4.8 \pm 1.4$ \\
\hline $\mathrm{CO}_{2}, \mathrm{~g} / \mathrm{kg}$ of $\mathrm{DM} \pm \mathrm{SD}$ & 0 & 116 & $33 \pm 29$ \\
\hline Yeasts $^{1}$ & $<2.0$ & 10.7 & $7.7 \pm 1.7$ \\
\hline Molds ${ }^{1}$ & $<2.0$ & 10.0 & $2.7 \pm 3.0$ \\
\hline
\end{tabular}

${ }^{1}$ Yeasts and molds are given as $\log _{10}(\mathrm{cfu} / \mathrm{g}$ of DM).

DMD and NDFD. The bias is defined as the mean of the 14 samples of (observed - predicted)/observed, and the error is defined as the square root of the mean sum of squares of the differences (Snedecor and Cochran, 1979). This process was repeated 10 times, each time excluding a different set of 14 random samples and using the prediction equations that were generated from the remaining samples.

\section{RESULTS}

Currently, the major wheat cultivar for ensiling in Israel is 'Galil', which was used in 83 of the 143 bunker silos sampled. It is a relatively late-maturing cultivar that reaches the milk stage during early April, 2 to 3 wk later than the early-maturing cultivars. Twenty-six of the silages were prepared from wheat harvested at the flowering stage, 82 at the milk stage, and the rest (35) at the dough stage of maturity.

Table 1 presents the ensiling (preservation) parameters of the wheat silage samples. The statistical analysis revealed that there were no significant $(P>$
$0.05)$ differences between years for these parameters, except for lactic acid and ethanol. The average values and standard deviations of the various parameters are based on the complete data set; for lactic acid and ethanol, the mean standard deviation was obtained from the standard deviations of the $3 \mathrm{yr}$. As expected, the major fermentation product was lactic acid, followed by acetic acid. Table 2 gives the mean values of the preservation parameters by maturity stage. Although there were statistically significant differences between the concentration of $\mathrm{DM}$ and $\mathrm{pH}$ values at different stages of maturity, these differences were not large. The concentrations of DM for wheat silages were similar for the various stages of maturity because wheat used for silage typically undergoes a short wilting period before harvest.

The aerobic stability of the commercial wheat silages was poor, based on the intensive $\mathrm{CO}_{2}$ production and increases in $\mathrm{pH}$ and yeast numbers (Tables 1 and 2). Sixty-seven of the sampled silages were treated with silage additives, which included various chemical additives (51 silos) and a lactic acid bacteria inoculant (16 silos). The $t$-test indicated that additives had a significant effect on minimizing $\mathrm{CO}_{2}$ production during aerobic exposure (overall means $=30$ and $37 \mathrm{~g} / \mathrm{kg}$ of DM for additive-treated and control silages, respectively; $P$ $=0.049$ ). However, additives did not have a significant effect on $\mathrm{pH}$ increase: the $\mathrm{pH}$ values increased from 3.8 to 4.0 in the fresh silage samples to an average of 4.5 and 5.1 in the additive-treated and control silages, respectively $(P=0.083)$. The interactions between additive and maturity were nonsignificant for both $\mathrm{pH}$ and $\mathrm{CO}_{2}$ production.

Table 3 presents the chemical composition of the wheat silage samples. The greatest ash values might represent soil contamination acquired during pickup. Table 4 presents the mean values of the chemical constituents by maturity stage. Silages prepared from the flowering wheat had significantly greater ash $(P=$ $0.031), \mathrm{CP}(P<0.0001)$, and NDF $(P=0.004)$ con-

Table 2. Preservation parameters of the wheat silages by maturity

\begin{tabular}{|c|c|c|c|c|}
\hline \multirow[b]{2}{*}{ Parameter } & \multicolumn{3}{|c|}{ Maturity } & \multirow[b]{2}{*}{ SEM } \\
\hline & Flowering & Milk & Dough & \\
\hline \multicolumn{5}{|l|}{ Fresh silage sample } \\
\hline $\mathrm{DM}, \mathrm{g} / \mathrm{kg}$ & $337^{\mathrm{b}}$ & $345^{\mathrm{ab}}$ & $361^{\mathrm{a}}$ & 3.5 \\
\hline $\mathrm{pH}$ & $3.9^{\mathrm{a}}$ & $3.8^{\mathrm{b}}$ & $3.7^{\mathrm{b}}$ & 0.02 \\
\hline Lactic acid, $\mathrm{g} / \mathrm{kg}$ of DM & 49 & 55 & 55 & 1.5 \\
\hline Ethanol, $\mathrm{g} / \mathrm{kg}$ of DM & 4 & 3 & 6 & 0.4 \\
\hline Acetic acid, $\mathrm{g} / \mathrm{kg}$ of DM & 22 & 22 & 20 & 0.8 \\
\hline \multicolumn{5}{|l|}{ After aerobic exposure } \\
\hline $\mathrm{pH}$ & 5.0 & 4.7 & 4.9 & 0.1 \\
\hline $\mathrm{CO}_{2}, \mathrm{~g} / \mathrm{kg}$ of $\mathrm{DM}$ & 33 & 36 & 34 & 2.3 \\
\hline
\end{tabular}

${ }^{a, b}$ Within rows, means followed by different superscripts are significantly different $(P<0.05)$. 
Table 3. Chemical composition and digestibility of the wheat silages $(\mathrm{g} / \mathrm{kg}$ of $\mathrm{DM} \pm \mathrm{SD})$

\begin{tabular}{lccc}
\hline Parameter & Minimum & Maximum & Average \\
\hline Ash & 59 & 152 & $90 \pm 14$ \\
CP & 62 & 146 & $109 \pm 16$ \\
NDF & 491 & 705 & $580 \pm 42$ \\
ADF & 324 & 473 & $387 \pm 28$ \\
Acid detergent lignin & 34 & 79 & $48 \pm 7$ \\
DM digestibility & 559 & 812 & $682 \pm 49$ \\
NDF digestibility & 322 & 721 & $535 \pm 72$ \\
\hline
\end{tabular}

centrations than silages made from more mature wheat; they also exhibited the greatest DMD and NDFD values $(P=0.086$ and 0.0004 , respectively). The ADF and ADL concentrations were similar across maturities $(P=0.350$ and 0.310 , respectively). Geographical area had a significant effect only on the concentration of CP $(P<0.0001)$ : wheat silages in southern Israel had the greatest $\mathrm{CP}$ concentration. This might be related to harvesting less mature wheat in the arid southern area, before the little water remaining in the soil from the scarce winter rains is depleted. The effect of area on other chemical constituents was nonsignificant, as was the interaction of area with maturity.

Table 5 presents the correlation coefficients between the chemical constituents of the wheat silages. Concentrations of $\mathrm{ADF}$ and $\mathrm{ADL}$ exhibited the closest correlations with DMD, whereas CP and NDF exhibited the closest correlations with NDFD. Concentrations of ADL were correlated negatively with DMD and NDFD.

The following prediction equations were obtained from the STEPWISE regression analysis for DM and NDF digestibility from all 143 samples:

$$
\begin{aligned}
& \mathrm{DMD}= 86.3+(0.70 \times \mathrm{CP})-(0.46 \times \mathrm{ADF}) \\
&-(1.67 \times \mathrm{ADL}), \text { and } \\
& \mathrm{NDFD}=20.3+(1.00 \times \mathrm{CP})+(1.16 \times \mathrm{NDF}) \\
&-(0.88 \times \mathrm{ADF})-(2.25 \times \mathrm{ADL}) .
\end{aligned}
$$

No terms for ash or NDF were included in the equation for DMD, nor was ash included in the equation for NDFD. The intercept values for DMD and NDFD were significantly different from zero $(P<0.0001$ and $P=0.010$, respectively). For DMD, the significance levels of the coefficients for $\mathrm{CP}, \mathrm{ADF}$, and $\mathrm{ADL}$ were $P=0.003, P=0.001$, and $P=0.001$, respectively. For NDFD, the significance levels for $\mathrm{CP}, \mathrm{NDF}, \mathrm{ADF}$, and ADL were $P=0.004, P<0.0001, P=0.013$, and $P=$ 0.001 , respectively.

Table 6 summarizes the model validation of the multiple regression analyses for DMD and NDFD, respectively. The mean bias was obtained from averaging the differences between the observed and predicted values, accounting for the plus-minus signs. The mean biases for DMD and NDFD were slightly negative, which means that the predicted values were lower overall than the values measured in vitro. The mean error (which represents the absolute differences between the observed and predicted values, without accounting for the plus-minus signs) for DMD was approximately $6.5 \%$, whereas that for NDFD was $11.8 \%$.

\section{DISCUSSION}

Silage management in Israel is dynamic, with constant changes in cultivars, additives, and bunker size (most silages in Israel are now managed in large bunker silos in regional feeding centers). In addition, with the current spiking prices of corn caused by biofuel production, wheat silage could be an alternative to corn silage in many areas around the world. Therefore, it is important to update the database pertaining to the quality of these wheat silages.

The current work had 2 objectives: 1) to obtain an updated quality status of commercial wheat silages in Israel, and 2) to develop prediction equations that would allow prediction of DMD and NDFD from chemical composition of the silage. The present study covered a total of 143 commercial wheat silage samples.

Table 4. Chemical composition and digestibility of the wheat silages $(\mathrm{g} / \mathrm{kg}$ of $\mathrm{DM})$ by maturity

\begin{tabular}{lcccc}
\hline & \multicolumn{3}{c}{ Maturity } \\
\cline { 2 - 3 } Parameter & Flowering & Milk & Dough & SEM \\
\hline Ash & $94^{\mathrm{a}}$ & $87^{\mathrm{b}}$ & $87^{\mathrm{b}}$ & 0.1 \\
CP & $115^{\mathrm{a}}$ & $109^{\mathrm{b}}$ & $94^{\mathrm{c}}$ & 0.1 \\
NDF & $594^{\mathrm{a}}$ & $579^{\mathrm{ab}}$ & $561^{\mathrm{b}}$ & 0.3 \\
ADF & 391 & 387 & 381 & 0.2 \\
Acid detergent lignin & 46 & 47 & 49 & 0.1 \\
DM digestibility & 696 & 681 & 661 & 0.4 \\
NDF digestibility & $566^{\mathrm{a}}$ & $534^{\mathrm{ab}}$ & $501^{\mathrm{b}}$ & 0.6 \\
\hline
\end{tabular}

${ }^{\mathrm{a}-\mathrm{c}}$ Within rows, means followed by different superscripts are significantly different $(P<0.05)$. 
Table 5. Correlation coefficients between the chemical constituents of the wheat silages

\begin{tabular}{|c|c|c|c|c|c|c|}
\hline Item & $\mathrm{CP}$ & NDF & $\mathrm{ADF}$ & Acid detergent lignin & DM digestibility & NDF digestibility \\
\hline $\begin{array}{l}\text { Ash } \\
\text { CP } \\
\text { NDF } \\
\text { ADF } \\
\text { Acid detergent lignin } \\
\text { DM digestibility }\end{array}$ & $0.288^{* *}$ & $\begin{array}{l}0.361^{* * *} \\
0.301^{* *}\end{array}$ & $\begin{array}{l}0.477^{* * *} \\
0.081^{\mathrm{NS}} \\
0.842^{* * *}\end{array}$ & $\begin{array}{l}0.065^{\mathrm{NS}} \\
0.066^{\mathrm{NS}} \\
0.132^{\mathrm{NS}} \\
0.199^{* *}\end{array}$ & $\begin{array}{l}-0.162^{*} \\
0.226^{* *} \\
-0.151^{*} \\
-0.294^{* *} \\
-0.323^{* * *}\end{array}$ & $\begin{array}{c}0.085^{\mathrm{NS}} \\
0.413^{* * *} \\
0.417^{* * *} \\
0.192^{* *} \\
-0.227^{*} \\
0.786^{* * *}\end{array}$ \\
\hline
\end{tabular}

${ }^{*} P<0.1 ;{ }^{* *} P<0.05 ;{ }^{* * *} P<0.001 ; \mathrm{NS}=$ not significant.

\section{Preservation Aspects}

The present study revealed that wheat silages are quite sensitive to aerobic exposure. In the bottle system that we used to determine aerobic stability, $\mathrm{CO}_{2}$ production and the $\mathrm{pH}$ increase correlated well with yeast and mold numbers and DM losses during aerobic exposure (Ashbell et al. 1991). We considered silages that produced less than $10 \mathrm{~g} / \mathrm{kg}$ of $\mathrm{DM}$ of $\mathrm{CO}_{2}$ and exhibited a $\mathrm{pH}$ increase of less than 0.5 units during the 5-d aerobic stability test to be stable. Overall, additives had some effect on retarding aerobic spoilage. No significant differences were found among the aerobic stability parameters associated with the various stages of maturity. This is in contrast to the findings of a previous study in mini silos in which silages prepared from wheat harvested at the flowering stage were more stable than those prepared from wheat harvested at the milk stage (Weinberg et al., 1998). The explanation for this discrepancy could be that air penetrates 1 to $2 \mathrm{~m}$ into the face of commercial bunker silages (Weinberg and Ashbell, 1994); therefore, commercial silage particles are exposed to air for a longer time than those in mini silos, which are completely sealed until sampling. This could have masked differences between silages made from wheat at different stages of maturity.

\section{Nutritional Aspects}

Silages prepared from young wheat at the flowering stage were found to be more digestible than those made from plants harvested at the milk or dough stages (Table 4), which is in agreement with the findings of a previous study (Arieli and Adin, 1994). Ashbell et al. (1997) recommended that wheat for silage be harvested at the milk ripening stage because of greater field yields, greater yields of DM and degradable NDF, and better ensiling quality. However, the dilemma of when to harvest wheat for silage was not resolved in the present study.

Silages prepared from flowering wheat had significantly greater NDF concentrations compared with those prepared from wheat at the milk and dough maturity stages (Table 4). This occurred because more mature plants contained grains filled with starch, which diluted the NDF concentration in the whole plants. We also expected a concomitant decrease in ADF concentration and an increase in ADL concentration in more mature plants (the greater ADL evolves from the development of the lignocellulose complex in older plants). Our results tended to reflect such changes, but with no statistical significance. The greater DMD and NDFD of the silages made from the flowering wheat, in spite of

Table 6. Validation statistics of the regression model for DM digestibility (DMD) and NDF digestibility $(\mathrm{NDFD})^{1}$

\begin{tabular}{|c|c|c|c|c|}
\hline \multirow[b]{2}{*}{ Validation } & \multicolumn{2}{|c|}{ DMD } & \multicolumn{2}{|c|}{ NDFD } \\
\hline & Bias & Error & Bias & Error \\
\hline 1 & -0.008 & 0.064 & 0.011 & 0.088 \\
\hline 2 & 0.021 & 0.057 & 0.023 & 0.101 \\
\hline 3 & 0.018 & 0.057 & 0.025 & 0.109 \\
\hline 4 & -0.007 & 0.068 & -0.016 & 0.121 \\
\hline 5 & -0.022 & 0.086 & -0.053 & 0.148 \\
\hline 6 & -0.005 & 0.606 & 0.008 & 0.095 \\
\hline 7 & -0.009 & 0.073 & -0.014 & 0.133 \\
\hline 8 & -0.043 & 0.071 & -0.011 & 0.132 \\
\hline 9 & -0.011 & 0.052 & -0.033 & 0.127 \\
\hline 10 & -0.006 & 0.060 & -0.012 & 0.127 \\
\hline Mean & -0.006 & 0.065 & -0.007 & 0.118 \\
\hline SD & 0.019 & 0.010 & 0.025 & 0.019 \\
\hline
\end{tabular}


the greater NDF concentration at this maturity, reflect the greater cell-wall digestibility of the young wheat, in which there is less linking between lignin and polysaccharides (Buxton and O'Kiely, 2003). Thus, NDFD might be a more reliable parameter than DMD in the silage quality assessment, because it reflects primarily the cell-wall digestibility of the leaf and stem portions of the silage, whereas DMD also includes dilution effects of the grain head.

The close correlation coefficients obtained between DMD and NDFD (Table 5) were expected, because fiber is the limiting factor in digestibility (Van Soest, 1982). Dry matter digestibility exhibited the closest correlation with the ADF and ADL concentrations, but for NDFD, the greatest correlations were obtained with the CP, NDF, and ADF concentrations.

One main objective of our study was to develop prediction equations for DMD and NDFD based on the chemical composition of the silage. Many studies have developed regression equations to predict digestibility from forage composition. However, such equations are not universal because of environmental and species variations (Van Soest, 1982). In the current study, we first chose from the chemical constituents that we considered the significant (ash, CP, NDF, ADF, ADL) terms by PROC STEPWISE. For DMD, these included $\mathrm{CP}, \mathrm{ADF}$, and ADL; for NDFD, the significant terms were $\mathrm{CP}, \mathrm{NDF}, \mathrm{ADF}$, and ADL. The regression analysis indicated that ADL and $\mathrm{CP}$ contents were the most important factors in determining DMD, whereas ADL was the most important factor in determining NDFD. In this context, the decrease in digestibility of silages prepared from mature plants was associated both with the lignin concentration and the cross-linking of lignin to polysaccharides in the plant cell wall (Buxton and O'Kiely, 2003). On the other hand, the youngest flowering wheat, which had the greatest $\mathrm{CP}$ content, also yielded silage with the greatest DMD and NDFD.

The biases (which accounted for the signs of the differences between the observed and predicted values) for the prediction equations for DMD and NDFD were slightly negative, indicating that the predicted values were slightly lower than the measured digestibility values. The error values (which represent the absolute differences between the observed and predicted values) for DMD and NDFD were 6.5 and $11.8 \%$, respectively. The error represents the absolute mean differences (ignoring the signs) between the observed and predicted values. Pitt et al. (1985) stated that overprediction of lactic acid by approximately $10 \%$ in their model of the ensiling process was "reasonably good." Hence, the prediction model for DMD was quite acceptable, whereas that of NDFD was less acceptable.

\section{CONCLUSIONS}

The present study resulted in an updated account of the preservation status and nutritional quality of wheat silages in Israel. Commercial wheat silages are sensitive to aerobic exposure; additives had some beneficial effects on the aerobic stability of the commercial wheat silages. The prediction equation obtained from the regression analysis for DMD resulted in acceptable matching to the measured in vitro DMD, whereas that for NDFD was less acceptable. Concentrations of ADL and $\mathrm{CP}$ were the most important factors in determining DMD, whereas ADL was the most important factor in determining NDFD.

\section{ACKNOWLEDGMENTS}

We would like to thank the following extension service personnel for their tremendous help with sample collection: Steven Rosen (Golan and Galilee), Hillel Malka (Yzrael valley), Daniel Verner (Sharon area), Gabi Adin (Central Plain), and Moshe Reches-Marito (Negev). We thank Hillary Voet from the Hebrew University of Jerusalem, Rehovot, Israel, and Richard Muck from the US Dairy Forage Research Center, Madison, Wisconsin, for their useful suggestions for the model validation. The research was supported by the Israeli Milk Board (Rishon Le Zion, Israel).

\section{REFERENCES}

Arieli, A., and G. Adin. 1994. Effect of wheat silage maturity on digestion and milk yield in dairy cows. J. Dairy Sci. 76:237-243.

Ashbell, G., Z.G. Weinberg, A. Azrieli, Y. Hen, and B. Horev. 1991. A simple system to study the aerobic deterioration of silages. Can. Agric. Eng. 33:391-394.

Ashbell, G., Z. G. Weinberg, I. Bruckental, K. Tabori, and N. Sharet. 1997. Wheat silage: effect of cultivar and stage of maturity on yield and degradability in situ. J. Agric. Food Chem. 45:709-712.

Barker, B., and W. H. Summerson. 1941. The colorimetric determination of lactic acid in biological material. J. Biol. Chem. 138:535-554.

Buxton, D. R., and P. O'Kiely. 2003. Preharvest plant factors affecting ensiling. Pages 199-250 in Silage Science and Technology. D. R. Buxton, R. E. Muck, and J. H. Harrison, ed. Am. Soc. Agron., Madison, WI.

Dubois, M., K. A. Gilles, J. K. Hamilton, P. A. Rebes, and F. Smith. 1956. Colorimetric method for determination of sugars and related substances. Anal. Chem. 28:350-356.

Pitt, R. E., R. E. Muck, and R. Y. Leibensperger. 1985. A quantitative model of the ensilage process in lactate silages. Grass Forage Sci. 40:279-303.

SAS Institute. 1982. User's Guide. SAS Inst. Inc., Cary, NC.

Snedecor, G. W., and W. G. Cochran. 1979. Design and analysis of sampling. Pages 504-539 in Statistical Methods. G. W. Snedecor and W. G. Cochran, ed. The Iowa State University Press, Ames.

Tilley, J. M. A., and R. A. Terry. 1963. A two stage technique for the in vitro digestion of forage crops. Brit. Grassl. 18:104-111.

Van Soest, P. J. 1982. Analytical systems for evaluation of feeds. Pages 75-94 in Nutritional Ecology of the Ruminant. P. J. Van Soest, ed. Cornell University Press, Ithaca, NY. 
Van Soest, P. J., J. B. Robertson, and B. A. Lewis. 1991. Methods for dietary fiber, neutral detergent fiber and non-starch polysaccharides in relation to animal nutrition. J. Dairy Sci. 74:3583-3597.

Weinberg, Z. G., and G. Ashbell. 1994. Changes in gas composition in corn silages in bunker silos during storage and feedout. Can. Agric. Eng. 36:155-158.

Weinberg, Z. G., G. Ashbell, Y. Chen, I. Bruckental, K. Tabori, and N. Sharet. 1998. The effect of stage of maturity at harvest of early and late maturing wheat cultivars on DM yields, cell-wall fractions, ensiling characteristics and degradability parameters. Final Report submitted to the Israeli Cattle Board. The Volcani Center, Bet Dagan, Israel. (in Hebrew)

Weinberg, Z. G., G. Ashbell, Y. Hen, and Z. Harduf. 1991. Ensiling whole wheat for ruminant feeding at different stage of maturity. Anim. Feed Sci. Technol. 32:313-320. 